Article

\title{
In Vitro Antimicrobial Activity of Essential Oils from Sardinian Flora against Cutibacterium (Formerly Propionibacterium) acnes and Its Enhancement by Chitosan
}

\author{
Claudia Juliano ${ }^{1, *(1)}$, Mauro Marchetti ${ }^{2}$, Maria Luisa Pisu ${ }^{1}$ and Marianna Usai ${ }^{1}$ \\ 1 Dipartimento di Chimica e Farmacia, Università degli Studi di Sassari, via Muroni 23/A, 07100 Sassari, Italy; \\ piggyland@tiscali.it (M.L.P.); dsfusai@uniss.it (M.U.) \\ 2 C.N.R.-Istituto di Chimica Biomolecolare, traversa La Crucca 3, 07040 Sassari, Italy, mauro@ss.cnr.it \\ * Correspondence: julianoc@uniss.it; Tel.: +39-79-228-729
}

Received: 15 August 2018; Accepted: 11 September 2018; Published: 13 September 2018

check for updates

\begin{abstract}
The in vitro antibacterial activity of some essential oils from Sardinian flora, both alone and in combination with chitosan, was investigated against a strain of Cutibacterium acnes, a bacterium involved in pathogenesis of acne. The composition of the essential oils was determined by gas chromatography and gas chromatography/mass spectrometry. The results of this investigation demonstrated that some of the oils examined, characterised by different chemical profiles, possessed some activity against $C$. acnes. Interestingly, this antibacterial effect was enhanced by sub-inhibitory concentrations of chitosan. These observations suggest the potential application of this synergy in the development of innovative topical formulations useful in the management of acne.
\end{abstract}

Keywords: Cutibacterium acnes; essential oils; antimicrobial activity; Santolina insularis; Juniperus oxycedrus; chitosan

\section{Introduction}

Acne vulgaris is a common skin disease that can affect people of all ages, with prevalence in up to $85 \%$ of teenagers and $11 \%$ of adults in Westernized populations [1-3]. It is a chronic multifactorial inflammatory disorder of the pilosebaceous follicles, typically affecting areas with the highest density of sebaceous follicles (face, upper chest and back), and is characterised by the presence of comedones, papular and pustular eruption, purulent cysts and scars [4]. Patients with acne present excessive sebum production, excessive keratosis of excretory ducts of sebaceous glands, development of bacterial flora and release of inflammatory mediators in the skin [4]. Acne has a complex and multifactorial pathogenesis, involving different key factors: androgen-mediated stimulation of sebaceous gland activity, altered follicular keratinisation, hormonal imbalance, inflammation, immune hypersensitivity, environmental factor (season, diet) and colonisation of the bacterium Cutibacterium acnes (formerly Propionibacterium acnes) [2-6].

C. acnes is a human, gram-positive anaerobic bacterium; although it is traditionally implicated in the pathogenesis of acne, its exact role in the pathophysiology of this disease is still debated. In general, it is present in acne lesions, but it is also a major commensal of the normal skin flora, often with similar concentrations in patients with acne and in healthy subjects; moreover, some acne lesions do not contain viable bacteria [7]. On the other hand, antibiotics that reduce $C$. acnes total count on acneic skin result in clinical improvement, and the presence of antibiotic-resistant Cutibacterium strains is associated with reduced efficacy of these treatments [7]. These controversial data may depend on inappropriate sampling methodologies used in qualitative and quantitative studies involving the 
role of $C$. acnes in acne, as recently suggested by Omer et al. [8]. Moreover, Fitz-Gibbon et al. [9] compared the skin microbiome (at the strain level and genome level) of $C$. acnes between a group of acne patients and a group of healthy individuals: although there was no statistically significant difference in the relative abundances of these bacteria in the cohorts studied, a strong association between specific bacterial ribotypes and acne was demonstrated. At present, a direct involvement of $C$. acnes appears certain; presumably it is not involved in the initiation of acne lesions, but would mediate later inflammatory events, leading to worsening of the lesions [5]. In particular, C. acnes stimulates the production of host antimicrobial peptides (AMP), small molecules with antimicrobial activity and immunomodulatory properties [10]; moreover, a lipase secreted by the bacterium is responsible for the hydrolysis of sebum and the subsequent release of free fatty acids, which have an irritating and proinflammatory effect [4].

Although acne vulgaris is a disease not life threatening nor physically debilitating, it poses serious psychological problem to patients, from impairment of self-esteem and self-confidence to anxiety, depression and even suicidal ideation, and its emotional impact is comparable to that of severe systemic diseases [11].

The approach to acne management depends on different factors (e.g., severity, age of the patient); a topical combined treatment (with benzoyl peroxide, retinoids, antibiotics) is recommended for mild to moderate acne, while the use of systemic therapies (with antibiotics, retinoids, oral contraceptives, androgen receptor blockers) is reserved for moderate to severe or refractory cases of acne [12-14]. However, the development of antibiotic resistance, the cost of the conventional therapies and their side effects have led to search for alternative remedies, including plants, plant extracts and phytomolecules [15-18]. In particular, some essential oils exhibited an interesting antibacterial activity against $C$. acnes [19-21]. The aim of the present study was to assess the in vitro inhibitory effect of some essential oils obtained from Sardinian plants against a strain of $C$. acnes. Moreover, we investigated an eventual synergistic interaction between some of these essential oils and chitosan, a partially deacetylated chitin of great biological interest characterized by multifunctional properties.

\section{Materials and Methods}

\subsection{Materials}

Stock solutions of the essential oils were prepared by dissolving them in PEG-200 in order to obtain a concentration of $100 \mathrm{mg} \mathrm{mL}^{-1}(10 \% w / v)$; solutions were then sterilized by filtration using sterile membrane filters (Sartorius, pore size $0.22 \mu \mathrm{m}$ ) and stored at $-20{ }^{\circ} \mathrm{C}$ until use. Chitosan (molecular weight 190-310 kDa; deacetylation degree 75-85\%; viscosity Brookfield, $1 \%$ solution in acetic acid 200-800 cps; manufacturer values) was supplied by Aldrich (Milwaukee, WI). Its aqueous solution was prepared by dissolving chitosan in hydrochloric acid $0.1 \mathrm{~mol} \mathrm{~L}^{-1}$ at $1 \% \mathrm{w} / \mathrm{vol}$ and by evaporating the resulting solution to dryness in a Rotavapor R110 (Buchi, Flawil, Switzerland) at $70{ }^{\circ} \mathrm{C}$ under vacuum; the residual was then redissolved in $100 \mathrm{~mL}$ of Milli-Q water and sterilised by filtration through $0.2 \mu \mathrm{m}$ Sartorious filters. The $\mathrm{pH}$ of this solution, evaluated with a $\mathrm{pH}$-meter Hanna 8417, was $2.35 \pm 0.04$.

Propionibacterium acnes ATCC 6919, Brain Heart Infusion Broth (BHI), Brain Heart Infusion Agar (BHA) and defibrinated horse blood were supplied by Thermo Fisher Scientific (Rodano, Italy). Anaerobic conditions were obtained in the Anaerobic Plus System with Gas Generating $\mathrm{Kit}_{2} / \mathrm{CO}_{2}$ (Oxoid, Milano, Italy).

\subsection{Plant Material and Isolation of Essential Oil}

Except for the Lavandula officinalis L. essential oils, purchased from Flora (Lorenzana, Pisa, Italy), the other essential oils were extracted in our laboratory. Aerial flowering plant materials of different botanical species were obtained from several locations during the months May and June 2016 during the same vegetative stage (anthesis), while Myrtus communis L. leaves were gathered in April; fruits 
from Juniperus oxycedrus L. ssp. macrocarpa (Sibth \& Sm.) Balland and Citrus limon var. pompia Camarda were collected in December and June, respectively. We collected aerial parts and fruits from all parts of the plants (top, sides and basis) to ensure that the samples were representative of the plants they came from. Before being processed, plant specimens were cleaned from any foreign matter. All species were identified by Prof. M. Usai, and a voucher specimen was deposited in the SASSA Herbarium of Department of Chemistry and Pharmacy, University of Sassari under collective numbers that will be reported below.

Fruits of Juniperus oxycedrus L. ssp. macrocarpa (Sibth \& Sm.) Balland were collected in December from plants growing in Cala Sarraina (Aglientu) $\left(41^{\circ} 05^{\prime} 00^{\prime \prime} \mathrm{N} 8^{\circ} 58^{\prime} 00^{\prime \prime} \mathrm{E}\right)\left(\mathrm{SASSA} \mathrm{N}^{\circ} 16529\right)$, while biomass (aerial parts) of Achillea maritima (L.) Ehrend. \& Y.P. Guo was collected in June from

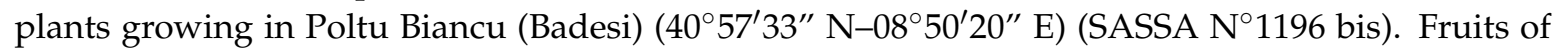
Citrus limon var. pompia Camarda were collected in March from plants growing in Siniscola $\left(40^{\circ} 34^{\prime} 24\right.$ N $9^{\circ} 41^{\prime} 49$ E) (SASSA N'231 septies). Leaves of Myrtus communis L. were collected in April (before blooming) from plants growing near Iglesias (39 $\left.18^{\prime} 41^{\prime \prime} \mathrm{N} 8^{\circ} 32^{\prime} 06^{\prime \prime} \mathrm{E}\right)$ (SASSA $\mathrm{N}^{\circ} 514$ ). Aerial parts of Santolina insularis (Fiori) Arrigoni were collected in June, at blooming time, in Gennargentu massif (Bruncu Spina 1.829 m) 4000'56.72” N 9¹8'14.29” E (SASSA N732). Thymus capitatus (L.) Hoffmanns. \& Link was collected in June at blooming time in San Michele in Plaiano, near Sassari $\left(40^{\circ} 47^{\prime} 24^{\prime \prime} \mathrm{N}\right.$ $8^{\circ} 31^{\prime} 4^{\prime \prime}$ E) (SASSA N¹078). Moreover, in June, we collected aerial parts of blooming Helichrysum microphyllum Cambess. subsp. tyrrhenicum Bacch., Brullo \& Giusso in four different stations of Sulcis (South-Western Sardinia). Station 1 is located $4 \mathrm{~km}$ from Iglesias (39 $18^{\prime} 41^{\prime \prime} \mathrm{N} 8^{\circ} 32^{\prime} 06^{\prime \prime}$ E). Station 2 is located $10 \mathrm{~km}$ from Carbonia $\left(39^{\circ} 09^{\prime} 52^{\prime \prime} \mathrm{N} 8^{\circ} 31^{\prime} 16^{\prime \prime} \mathrm{E}\right)$, Station 3 is located in Portoscuso area $\left(39^{\circ} 12^{\prime} 26^{\prime \prime} \mathrm{N} 8^{\circ} 22^{\prime} 51^{\prime \prime} \mathrm{E}\right)$ and Station 4 is located $19 \mathrm{~km}$ from Oristano (39 $\left.54^{\prime} 12^{\prime \prime} \mathrm{N} 8^{\circ} 35^{\prime} 33^{\prime \prime} \mathrm{E}\right)$ (SASSA cumulative $\mathrm{N}^{\circ} 729$ ).

The essential oil samples were obtained from fresh materials by hydro-distillation for 4-5 h using a Clevenger-type apparatus. The extraction yield was calculated in $\mathrm{mL}$ of oil for $100 \mathrm{~g}$ of fresh material. The reached yields are reported in Figure 1.

Differences between yields may be explained considering that essential oils were obtained from different parts of plants. T. capitatus flowering aerial parts gave the higher yield (1.08\%), while Juniperus oxycedrus L. ssp. macrocarpa fruits gave the lower yield (0.14\%). All the other samples, except Achillea maritima aerial part $(0.52 \%)$, gave a yield varying from $0.38 \%$ to $0.45 \%$. The oils were kept refrigerated in sealed vials at $-20^{\circ} \mathrm{C}$ until used.

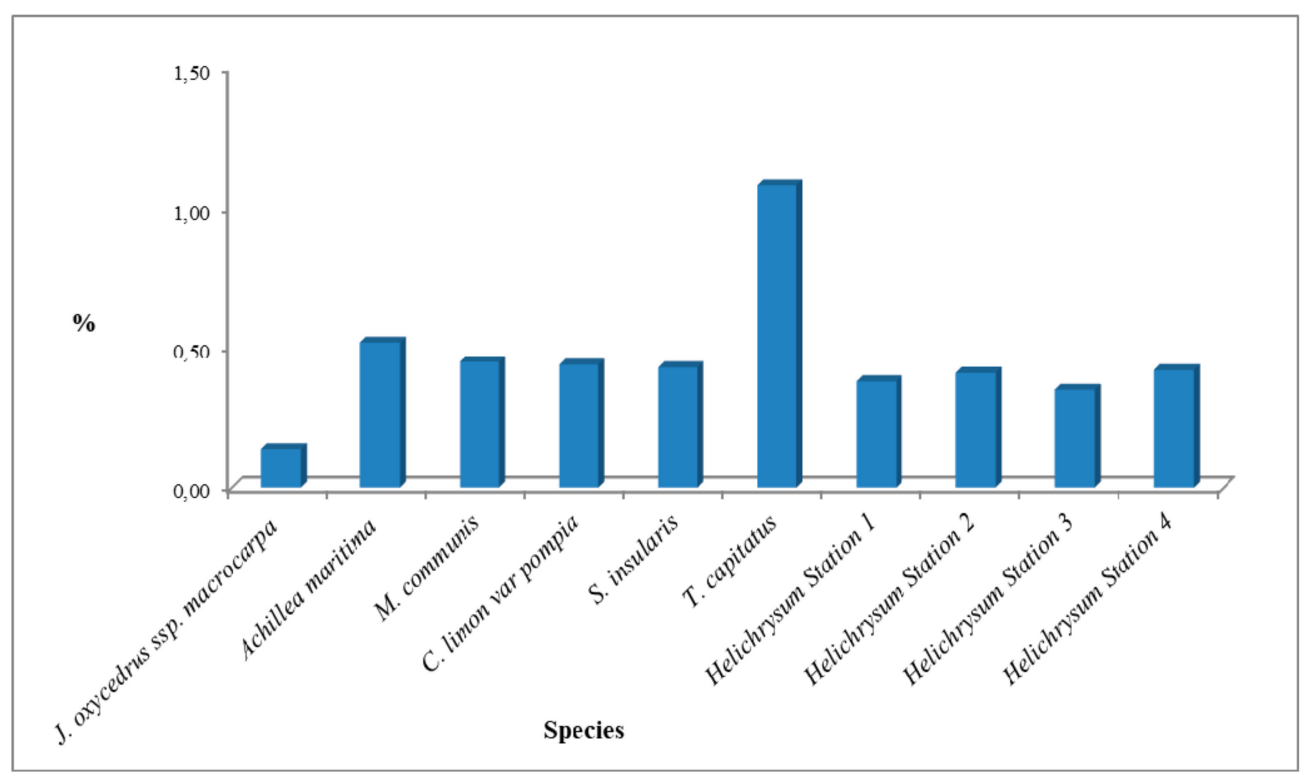

Figure 1. Yields of essential oils belonging to different species. 


\subsection{Oil Analyses and Quantification}

GC (Gas chromatography)-Three replicates of each sample were analysed using a Hewlett-Packard Model 5890A GC equipped with a flame ionization detector and fitted with a $60 \mathrm{~m}$ $\times 0.25 \mathrm{~mm}$, thickness $0.25 \mu \mathrm{m}$ ZB-5 fused silica capillary column (Phenomenex). Injection port and detector temperature were $280{ }^{\circ} \mathrm{C}$. The column temperature was programmed from $50{ }^{\circ} \mathrm{C}$ to $135^{\circ} \mathrm{C}$ at $5{ }^{\circ} \mathrm{C} / \mathrm{min}(1 \mathrm{~min}), 5^{\circ} \mathrm{C} / \mathrm{min}$ up $225^{\circ} \mathrm{C}(5 \mathrm{~min}), 5^{\circ} \mathrm{C} / \mathrm{min}$ up $260^{\circ} \mathrm{C}$ and held for $10 \mathrm{~min}$.

The samples $(0.1 \mu \mathrm{L}$ each), generally analysed without dilution (using 2,6-dimethylphenol as internal standard), were injected using a split/splitless automatic injector HP 7673 and using helium as carrier gas. Several measurements of peak areas were performed with a workstation with a threshold set at 0 and peak width at 0.02 . The quantization of each compound was expressed as absolute weight percentage using internal standard and response factors. The detector response factors (RFs) were determined for key components relative to 2,6-dimethylphenol and assigned to other components on the basis of functional group and/or structural similarity, since oxygenated compounds have lower detectability by F.I.D. than hydrocarbons. The standards were $>95 \%$ also, and actual purity was checked by GC. Several response factor solutions were prepared that consisted of only four or five components (plus 2,6-dimethylphenol) to prevent interference from trace impurities.

It is known that the oxygenated compounds have a lower sensitivity than the hydrocarbons to F.I.D. We have calculated the response factor using a standard mixture of $\alpha$-pinene, $\alpha$-terpineol, neral, geranial, geranyl acetate and caryophyllene; in this mixture terpenes accounted for $92 \%$ of the mixture, aldehydes $5 \%$ and alcohols, esters and sesquiterpenes $1 \%$ each. In our analysis we obtained that the $\mathrm{RF}$ of hydrocarbons was equal to 1 , while for alcohols it was 0.80 and for esters 0.71 . For this reason, we have multiplied the experimental data obtained for the following correction factors: hydrocarbons for 1, aldehydes and ketones for 1.24, alcohols for 1.28 and esters for 1.408.

GC/MS (Gas chromatography/Mass): MS analyses were carried out with an Agilent Technologies model 7820 A connected with a MS detector 5977E MSD (Agilent) and using the same conditions and column described above. The column was connected to the ion source of the mass spectrometer. Mass units were monitored from 10 to $900 \mathrm{AMU}$ at $70 \mathrm{eV}$. In the identification procedure we considered only the peaks from 40 to 900 AMU. The identification of compounds was based on comparison of their retention times with those of authentic samples and/or by comparison of their mass spectra with those of published data [22,23] or on the interpretation of the EI-fragmentation of the molecules.

\subsection{Antimicrobial Activity of Essential Oils and Chitosan}

Antimicrobial activity of essential oils against $C$. acnes was determined by evaluating their Minimum Inhibitory Concentration (M.I.C.) and Minimum Bactericidal Concentration (M.B.C.) values. M.I.C. values were evaluated in 96-well round-bottom microtiter plates by a broth microdilution technique, as described in [24]. Briefly, two-fold dilutions of the stock solution of the oil, ranging from $4 \mathrm{mg} \mathrm{mL}^{-1}$ to $0.063 \mathrm{mg} \mathrm{mL}^{-1}$, were prepared in triplicate in BHI; control wells contained only liquid medium and liquid medium with the highest concentration of PEG-200 used. As positive control, erythromycin (from 12.5 to $0.012 \mu \mathrm{g} / \mathrm{mL}$; mother solution $2 \mathrm{mg} / \mathrm{mL}$ in distilled water) was used. Microplates were inoculated with about $1 \times 10^{4}$ bacteria/well incubated at $35^{\circ} \mathrm{C}$ for $72 \mathrm{~h}$ in anaerobic conditions. After incubation, plates were visually checked for bacterial growth and the M.I.C.s were defined as the lowest concentration at which no growth was observed. PEG-200 had no inhibitory effect on the growth of microorganisms at all concentrations tested. To determine the M.B.C. aliquots of $10 \mu \mathrm{L}$ of medium from each well with no visible growth were subcultured onto Blood Agar Sheep plates, which were then incubated at $35^{\circ} \mathrm{C}$ for $24 \mathrm{~h}$; $\mathrm{MBC}$ was defined as the lowest concentration at which no growth was detectable. Unless otherwise specified, all assays were performed in triplicate.

The M.I.C. and M.B.C. values of chitosan solution against C. acnes were determined as described above; for M.I.C. evaluation, chitosan solution was subjected to two-fold serial dilutions (2-0.0039 $\mathrm{mg} / \mathrm{mL}$ ) in BHI (whose $\mathrm{pH}$ value did not change after chitosan solution addition). 
2.5. Antibacterial Activity of M. communis, S. insularis and J. oxycedrus Essential Oils in the Presence of Sub-Inhibitory Concentrations of Chitosan

The antimicrobial activity of some of the oils tested (M. communis, S. insularis and J. oxycedrus), characterized by a well-documented antioxidant activity potentially helpful in acne, were subjected to further investigation. MIC and MBCs of these essential oils against C. acnes were evaluated, as previously described, in the presence of sub-inhibitory concentration of chitosan $(0.031 \mathrm{mg} / \mathrm{mL}$, corresponding to one-half of the MIC value of chitosan). The results of these experiments are reported in Table 1.

Table 1. Minimum Inhibitory Concentration (M.I.C.) of Myrtus communis, Santolina insularis and Juniperus oxycedrus essential oils against Cutibacterium acnes in the presence of a sub-inhibitory concentration of chitosan (M.I.C. chitosan against C. acnes $=0.063 \mathrm{mg} / \mathrm{mL}$ ) (mean of 3 experiments).

\begin{tabular}{cccc}
\hline & e.o. M. communis & e.o. S. insularis & e.o. J. oxycedrus \\
\hline MIC of essential oil & $>4 \mathrm{mg} / \mathrm{mL}$ & $1 \mathrm{mg} / \mathrm{mL}$ & $1 \mathrm{mg} / \mathrm{mL}$ \\
MIC of essential oil $+0.031 \mathrm{mg} / \mathrm{mL}$ chitosan & $1.5 \mathrm{mg} / \mathrm{mL}$ & $0.063 \mathrm{mg} / \mathrm{mL}$ & $0.094 \mathrm{mg} / \mathrm{mL}$ \\
\hline
\end{tabular}

\section{Results}

\subsection{Essential Oils Characterization}

Uncoloured, yellow and blue liquid oils are the result of the hydrodistillation of the aerial parts, lives and fruits of the different used species. Overall, numerous compounds were identified for every sample, representing from a minimum amount of $88.97 \%$ to a maximum of $99.73 \%$ of the total composition. One hundred eighty-one compounds were detected and quantified by GC and GC/MS methods in the studied oils. All these constituents were identified on the basis of their mass spectra, retention indices and/or by comparison with authentic compounds [22,23]. The analytical data are the average of three injections. Each one of the eleven samples shows a very peculiar chromatographic profile. The complete characterization of the essential oils is reported in Table S1 (Supplementary File).

Among the analyzed plants we observed that the fruits of Juniperus oxycedrus L. ssp. macrocarpa (Sibth \& Sm.), collected in December, were characterized by an essential oil in which the main constituent is represented by a very higher percentage of pinene, $77.63 \%$ on $91.54 \%$ of identified compounds. With the exception of germacrene D (3.5\%), all the other constituents are present in concentration $<1 \%$. No other essential oil among those investigated exhibits a similar chromatographic profile.

From the aerial parts of Achillea maritima (L.) Ehrend. \& Y.P. Guo an essential oil with a very stable dark blue colour was obtained, in which some constituents in high concentration could be identified. The blue colour is due to azulenes, in particularly to chamazulene $(0.38 \%)$. Yomogi alcohol reached the concentration of $22.83 \%$, artemisia alcohol $17.18 \%$ and camphor $20.82 \%$. Other remarkable constituents were camphene (5.38\%), artemysil acetate (5.28\%) and crysantenone (3.38\%). With the exception of camphor, all the other mentioned compounds were not found in the other analysed oils.

We also analysed a commercial essential oil of Lavandula officinalis L. that has a concentration of $32.01 \%$ of linalool, $28.65 \%$ of linalyl acetate, $7.4 \%$ of camphor and $5.07 \%$ of linalyl acetate.

The essential oil obtained from flamed of Citrus limon var. pompia Camarda fruits was colorless and characterized by the presence of $88.23 \%$ of limonene followed by a $2 \%$ of myrcene; typical constituents of the oils of Citrus species, such as neral, geranial and geraniol (1.15\%, 1.56\% and 1.23\% respectively), were also identified. All the other constituents were present in very low concentration.

The essential oil extracted from $M$. communis leaves had as principal constituents $\alpha$-pinene $(52.72 \%), 1,8$-cineole $(16.11 \%)$ and limonene $(6.53 \%)$.

The aerial parts of Santolina insularis (Fiori) Arrigoni gave a yellow essential oil rich in artemisia ketone $(24.61 \%)$ and $\beta$-phellandrene (18.87\%), which were the main constituents. Other constituents in 
high concentration were santolina triene (9.32\%), found only in this essential oil, 1 S-pinene (7\%) and myrcene $(5.15 \%)$.

Thymus capitatus (L.) Hoffmanns. \& Link, as many Thymus species, was characterized by a high carvacrol concentration (57\%); other important constituents were o-cymene $(8.65 \%), \gamma$-terpinene $(6.92 \%), 3.7 \%$ of myrcene and $\alpha$-thujene.

Four samples of Helichrysum microphyllum Cambess. subsp. tyrrhenicum Bacch., Brullo and Giusso were collected in four stations located in South-West of Sardinia. The four essential oils obtained were very different each other; in particular the samples coming from Station 1 (Iglesias) and Station 2 (Carbonia) were characterized by an unusual concentration of $\gamma$-curcumene (more than $28 \%$ ). The essential oil obtained from plants collected in Station 3 (Portoscuso) presents many constituents with concentration among 1 and $2 \%$ and the main constituents are represented by $\gamma$-curcumene (12.22\%), linalool (11.47\%), 5-eudesmen-11-ol (10.35\%) and nerolidol (5.07\%). The oil from station 4 (Oristano) showed the chromatographic profile expected for this species growing in middle and North Sardinia and is very rich in geranyl acetate (33.6\%).

\subsection{Antimicrobial Activity of the Essential Oils against C. acnes}

The results of the antibacterial screening of the essential oils examined are summarized in Table 2. The oils showed different levels of inhibition; the essential oil obtained from T. capitatus exhibited the highest activity against $C$. acnes, with MIC and MBC values of 0.25 and $0.5 \mathrm{mg} / \mathrm{mL}$ respectively. C. lemon var. pompia and Lavandula essential oils demonstrated significantly lower activity (MIC values $4 \mathrm{mg} / \mathrm{mL}$ ), while $C$. acnes growth was not affected by $M$. communis oil at the highest concentration tested (MIC $>4 \mathrm{mg} / \mathrm{mL}$ ). Other essential oils presented moderate activity against P. acnes, with MIC values ranging from 1 to $2 \mathrm{mg} / \mathrm{mL}$. The MIC of the reference standard erythromycin against $C$. acnes was $0.024 \mu \mathrm{g} / \mathrm{mL}$.

Table 2. Minimum inhibitory concentration (M.I.C.) and minimum bactericidal concentration (M.B.C.) of ten essential oils against Cutibacterium acnes ATCC 6919 (mean of 3 experiments, with the exceptions of $S$. insularis - mean of 7 experiments- and J. oxycedrus - mean of 5 experiments) (n.d. = not determined).

\begin{tabular}{ccc}
\hline Essential Oil & M.I.C. & M.B.C. \\
\hline Thymus capitatus & $0.25 \mathrm{mg} / \mathrm{mL}$ & $0.5 \mathrm{mg} / \mathrm{mL}$ \\
Santolina insularis & $1 \mathrm{mg} / \mathrm{mL}$ & $2 \mathrm{mg} / \mathrm{mL}$ \\
Helichrysum microphyllum subsp. tyrrhenicum (Station 1) & $1 \mathrm{mg} / \mathrm{mL}$ & $2 \mathrm{mg} / \mathrm{mL}$ \\
Helichrysum microphyllum subsp. tyrrhenicum (Station 2) & $2 \mathrm{mg} / \mathrm{mL}$ & $4 \mathrm{mg} / \mathrm{mL}$ \\
Helichrysum microphyllum subsp. tyrrhenicum (Station 3) & $1 \mathrm{mg} / \mathrm{mL}$ & $\mathrm{n} . \mathrm{d}$. \\
Achillea maritima & $2 \mathrm{mg} / \mathrm{mL}$ & $4 \mathrm{mg} / \mathrm{mL}$ \\
Juniperus oxycedrus & $1 \mathrm{mg} / \mathrm{mL}$ & $2 \mathrm{mg} / \mathrm{mL}$ \\
Citrus limon var. pompia & $4 \mathrm{mg} / \mathrm{mL}$ & $>4 \mathrm{mg} / \mathrm{mL}$ \\
Lavandula officinalis & $4 \mathrm{mg} / \mathrm{mL}$ & $\mathrm{n} . \mathrm{d}$. \\
Myrtus communis & $>4 \mathrm{mg} / \mathrm{mL}$ & $>4 \mathrm{mg} / \mathrm{mL}$ \\
\hline
\end{tabular}

3.3. Antibacterial Activity of M. communis, S. insularis and J. oxycedrus Essential Oils in the Presence of Sub-Inhibitory Concentrations of Chitosan

In our experimental conditions, $\mathrm{MIC}$ and $\mathrm{MBC}$ values of chitosan against $\mathrm{C}$. acnes resulted 0.063 and $0.25 \mathrm{mg} / \mathrm{mL}$ respectively. When evaluated in presence of a concentration of chitosan of half the MIC $(0.031 \mathrm{mg} / \mathrm{mL})$, the antimicrobial activity of some of the essential oils examined was significantly enhanced (Table 2). In particular, M. communis essential oil, that alone did not show any inhibitory activity at the highest concentration tested $(4 \mathrm{mg} / \mathrm{mL})$, became active (MIC $1.5 \mathrm{mg} / \mathrm{mL}$ ) when combined with chitosan. Moreover, the presence of sub-inhibitory concentrations of chitosan significantly improved the antibacterial properties of essential oils of $S$. insularis (whose MIC was reduced by $1 \mathrm{mg} / \mathrm{mL}$ to $0.063 \mathrm{mg} / \mathrm{mL}$ ) and J. oxycedrus (whose MIC value decreased from 1 to $0.094 \mathrm{mg} / \mathrm{mL})$. 


\section{Discussion}

Among the essential oils investigated in the present study, T. capitatus oil showed the most marked inhibitory activity against $C$. acnes; this result is not unexpected, because the activity of essential oils from other Thymus species against P. acnes has been reported [20,24]. On the other hand, this paper documents for the first time the antimicrobial activity towards $C$. acnes of essential oils obtained from plant typical of Sardinian flora; this is interesting, because essential oils are currently being investigated, amongst other plant-derived products, for their application in acne management [16].

Some of the essential oils deriving from Sardinian wild plants examined in this investigation possess an antimicrobial activity of interest. As far as T. capitatus is concerned, it is likely that its high content of carvacrol justify its activity. Carvacrol, or cymophenol, is a phenolic monoterpene present in the essential oils of oregano and thyme. It is the substance that imparts to oregano its characteristic odor. It is a regioisomer of thymol and its antimicrobial activity is well-known [25,26]. In essential oils of Helichrysum (Station 1 and 3) linalool, a compound with anti-inflammatory activity [27], 5-eudesmen-11-ol, an oxygenated sesquiterpene, and $\gamma$-curcumene have been reported. These compounds are normally found in Helichrysum essential oil which shows an antimicrobial activity as reported in [28]. Moreover, Rossi et al. [29] demonstrated that the essential oil obtained from endemic plants of Corsica is more effective on the Gram-positive bacterium S. aureus than on the Gram-negative strains Escherichia coli, Enterobacter aerogenes and Pseudomonas aeruginosa.

Essential oil sample from J. oxycedrus contained a very high concentration of $\alpha$-pinene, which possesses anti-inflammatory and antibacterial activities, as reported in [30]. The large amount of this compound could explain the antibacterial activity observed in our investigation.

The activity of $S$. insularis is probably due to the presence of artemisia ketone, $\beta$-phellandrene as main constituents; Radulović et al. [31] demonstrated that artemisia ketone has a stronger free radical scavenging effect and a stronger antimicrobial activity when compared to other well-known monoterpenes. Moreover $\beta$-phellandrene is reported to exhibit antifungal and antibacterial activities, according to [32]. In the study, it was stated that nerolidol, sabinene and $\beta$-phellandrene was reported to possess antibacterial and antifungal activity.

To complete our investigation, we studied an eventual synergistic interaction between some of these essential oils and chitosan, a partially deacetylated chitin with multifunctional properties, including bioadhesivity, biodegradability and bio-compatibility, which make it an attractive biomaterial for pharmaceutical purposes; in addition to the abovementioned properties, chitosan possesses interesting antimicrobial and antioxidant activities. The exact mechanism of the antimicrobial activity of chitosan is still unknown; it depends on intrinsic factors of the polymer (molecular weight, positive charge density, chelating capacity, physical state), environmental factors ( $\mathrm{pH}$, ionic strength, temperature) and microbial factors (cell age, microbial species) [33]. In particular, chitosan demonstrated in vitro antimicrobial activity, dose- and $\mathrm{pH}$-dependent, against two common cutaneous pathogens, Staphylococcus aureus and C. acnes [34]. Moreover, some studies demonstrated that the combination of chitosan and essential oils results in an increase of the oil antimicrobial efficacy [35-37]. Some of the essential oils tested (M. communis, J. oxycedrus, and S. insularis), exhibiting an inhibitory activity moderate or even no activity against $C$. acnes, still possess a well-documented antioxidant activity [38-40]. It is well known that in acne the reactive oxygen species (ROS) produced by neutrophils play a critical role in the irritation and destruction of the follicular wall and are responsible for the progression of acne [41]; therefore, essential oils with antioxidant activity could have beneficial effects in acne management. Consequently, essential oils with good antioxidant activity but little antimicrobial effect can be combined with chitosan to improve their potential utility as multifunctional ingredients of topical anti-acne formulations. Actually, our experimental data showed that the combination of sub-inhibitory concentrations of chitosan $(0.031 \mathrm{mg} / \mathrm{mL}$, namely half of the minimum inhibitory concentration) with essential oils of M. communis, J. oxycedrus and S. insularis significantly improved their antibacterial activity against $P$. acnes, bringing unexpected chances to use them as adjuvants in the complex clinical situation of acne. 


\section{Conclusions}

Our investigation has been focused on the evaluation of the in vitro inhibitory effect of some essential oils obtained from Sardinian plants against a strain of C. acnes, with the purpose to re-evaluate traditional ethnobotanical resources. On the basis of the well-known antioxidant activity and of the antibacterial activity against $C$. acnes of some of the oils investigated, and considering the synergism chitosan-essential oil, it seems appropriate to consider them for further formulative and pharmacological investigations.

Supplementary Materials: The following are available online at http:/ /www.mdpi.com/2218-0532/86/3/40/s1, Table S1: Characterization of the essential oils used for antimicrobial tests.

Author Contributions: C.J. and M.L.P. conceived and conducted the microbiology experiments; M.M. and M.U. conducted the extraction and the characterization of the essential oils; C.J. wrote the article.

Funding: This research did not receive any specific grant from funding agencies in the public, commercial or not-for-profit sectors.

Acknowledgments: We thank Barbara Sechi for her skilled help in analyses GC/MS of the essential oils; we also thank Gaia Trebini for critical revision of English contents.

Conflicts of Interest: The authors declare no conflict of interest.

\section{References}

1. White, G.M. Recent findings in the epidemiologic evidence, classification and subtypes of acne vulgaris. J. Am. Acad. Dermatol. 1998, 39, S34-S37. [CrossRef]

2. Melnik, B.C. Acne vulgaris: The metabolic syndrome of the pilosebaceous follicle. Clin. Dermatol. 2018, 36, 29-40. [CrossRef] [PubMed]

3. Monfrecola, G.; Lembo, S.; Caiazzo, G.; de Vita, V.; Di Caprio, R.; Balato, A.; Fabbrocini, G. Mechanistic target of rapamycin (mTOR) expression is increased in acne patients' skin. Exp. Dermatol. 2016, 25, 153-155. [CrossRef] [PubMed]

4. Bergler-Czop, B. The aetiopathogenesis of acne vulgaris-What's new? Int. J. Cosmet. Sci. 2014, 36, 187-194. [CrossRef] [PubMed]

5. Zouboulis, C.C.; Eady, A.; Philpott, M.; Goldsmith, L.A.; Orfanos, C.; Cunliffe, W.C.; Rosenfield, R. What is the pathogenesis of acne? Exp. Dermatol. 2005, 14, 143-152. [CrossRef] [PubMed]

6. Kumar, B.; Pathak, R.; Mary, P.B.; Jha, D.; Sardana, K.; Gautam, H.K. New insights into acne pathogenesis: Exploring the role of acne-associated microbial population. Dermatol. Sin. 2016, 34, 67-73. [CrossRef]

7. Dessiniotis, C.; Katsambas, A.D. The role of Propionibacterium acnes in acne pathogenesis: Facts and controversies. Clin. Dermatol. 2010, 28, 2-7. [CrossRef] [PubMed]

8. Omer, H.; McDowell, A.; Alexeyev, O.A. Understanding the role of Propionibacterium acnes in acne vulgaris: The critical importance of skin sampling methodologies. Clin. Dermatol. 2017, 35, 118-129. [CrossRef] [PubMed]

9. Fitz-Gibbon, S.; Tomida, S.; Chiu, B.-H.; Nguyen, L.; Du, C.; Liu, M.; Elashoff, D.; Erfe, M.C.; Loncaric, A.; Kim, J.; et al. Propionibacterium acnes strain populations in the human skin microbiome associated with acne. J. Investig. Dermatol. 2013, 133, 2152-2160. [CrossRef] [PubMed]

10. Harder, J.; Tsuruta, D.; Murakami, M.; Kurokawa, I. What is the role of antimicrobial peptides (AMP) in acne vulgaris? Exp. Dermatol. 2013, 22, 386-391. [CrossRef] [PubMed]

11. Hosthota, A.; Bondade, S.; Basvaraja, V. Impact of acne vulgaris on quality of life and self-esteem. Cutis 2016, 98, 121-124. [PubMed]

12. Kraft, J.; Freiman, A. Management of acne. Can. Med. Assoc. J. 2011, 183, E430-E435. [CrossRef] [PubMed]

13. Harper, J.C. Use of oral contraceptives for management of acne vulgaris: Practical considerations in real world practice. Dermatol. Clin. 2016, 34, 159-165. [CrossRef] [PubMed]

14. Harris, V.R.; Cooper, A.J. Modern management of acne. Med. J. Aust. 2017, 206, 41-45. [CrossRef]

15. Azimi, H.; Fallah-Tafti, M.; Khakshur, A.A.; Abdollai, M. A review of phytotherapy of acne vulgaris: Perspective of new pharmacological treatments. Fitoterapia 2012, 83, 1306-1317. [CrossRef] [PubMed] 
16. Sinha, P.; Srivastava, S.; Mishra, N.; Prasad Yadav, N. New perspectives on antiacne plant drugs: Contribution to modern therapeutics. BioMed Res. Int. 2014, 2014, 301304. [CrossRef] [PubMed]

17. Julianti, E.; Rajah, K.K.; Fidrianny, I. Antibacterial activity of ethanolic extract of cinnamon bark, honey, and their combination effects against acne-causing bacteria. Sci. Pharm. 2017, 85, 19. [CrossRef] [PubMed]

18. Jantarat, C.; Sirathanarun, P.; Chuchue, T.; Konpian, A.; Sukkua, G.; Wongprasert, P. In vitro antimicrobial activity of gel containing the herbal ball extract against Propionibacterium acnes. Sci. Pharm. 2018, 86, 8. [CrossRef] [PubMed]

19. Lertsatitthanakorn, P.; Taweechaisupapong, S.; Aromdee, C.; Khunkitti, W. In vitro bioactivities of essential oils used for acne control. Int. J. Aromather. 2006, 16, 43-49. [CrossRef]

20. Zu, Y.; Yu, H.; Liang, L.; Fu, Y.; Efferth, T.; Liu, X.; Wu, N. Activities of ten essential oils towards Propionibacterium acnes and PC-3, A-549 and MCF-7 cancer cells. Molecules 2010, 15, 3200-3210. [CrossRef] [PubMed]

21. Hammer, K.A. Treatment of acne with tea tree oil (melaleuca) product: A review of efficacy, tolerability and potential modes of action. Int. J. Antimicrob. Agents 2015, 45, 106-110. [CrossRef] [PubMed]

22. NIST 2011 Library of Mass Spectra; Agilent Technologies Co.: Palo Alto, CA, USA, 2011.

23. Adams, R.P. Identification of Essential Oil Components by Gas Chromatography/Mass Spectrometry; Allured Publishing Corporation: Carol Stream, IL, USA, 2007.

24. Bonferoni, M.C.; Cerri, G.; de' Gennaro, M.; Juliano, C.; Caramella, C. Zn ${ }^{++}$-exchanged clinoptilolite-rich rock as active carrier for antibiotics in anti-acne topical therapy. In vitro characterization and preliminary formulation studies. Appl. Clay Sci. 2007, 36, 95-102. [CrossRef]

25. Oh, T.-H.; Kim, S.-S.; Yoon, W.-J.; Kim, J.-Y.; Yang, E.-J.; Lee, N.H.; Hyun, C.-G. Chemical composition and biological activities of Jeju Thymus quinquecostatus essential oils against Propionibacterium species inducing acne. J. Gen. Appl. Microbiol. 2009, 55, 63-68. [CrossRef] [PubMed]

26. Du, E.; Gan, L.; Li, Z.; Wang, W.; Liu, D.; Guo, Y. In vitro antibacterial activity of thymol and carvacrol and their effects on broiler chickens challenged with Clostridium perfringens. J. Anim. Sci. Biotechnol. 2015, 6, 58. [CrossRef] [PubMed]

27. Peana, A.T.; D’Aquila, A.T.; Panin, F.; Serra, G.; Pippia, P.; Moretti, M.D. Anti-inflammatory activity of linalool and linalyl acetate constituents of essential oils. Phytomedicine 2002, 9, 721-726. [CrossRef] [PubMed]

28. Djihane, B.; Wafa, N.; Elkhamassa, S.; Pedro, H.J.; Maria, A.E.; Mohamed Mihoub, Z. Chemical constituents of Helichrysum italicum (Roth) G. Don essential oil and their antimicrobial activity against Gram-positive and Gram-negative bacteria, filamentous fungi and Candida albicans. Saudi Pharm. J. 2017, 25, 780-787. [CrossRef] [PubMed]

29. Rossi, P.-G.; Berti, L.; Panighi, J.; Luciani, A.; Maury, J.; Muselli, A.; De Rocca Serra, D.; Gonny, M.; Bolla, J.-M. Antibacterial action of essential oils from Corsica. J. Essent. Oil Res. 2007, 19, 176-182. [CrossRef]

30. Yesil Celiktas, O.; Hames Kocabas, E.E.; Bedir, E.; Vardar Sukan, F.; Ozek, T.; Baser, K.H.C. Antimicrobial activities of methanol extracts and essential oils of Rosmarinus officinalis, depending on location and seasonal variations. Food Chem. 2007, 100, 553-559. [CrossRef]

31. Radulović, N.S.; Randjelović, P.J.; Stojanović, N.M.; Blagojević, P.D.; Stojanović-Radić, Z.Z.; Ilić, I.R.; Djordjević, V.B. Toxic essential oils. Part II: Chemical, toxicological, pharmacological and microbiological profiles of Artemisia annua L. volatiles. Food Chem. Toxicol. 2013, 58, 37-49. [CrossRef] [PubMed]

32. Mneimne, M.; Baydoun, S.; Nemer, N.; Apostolides, N.A. Chemical Composition and Antimicrobial Activity of Essential Oils Isolated from Aerial Parts of Prangos asperula Boiss. (Apiaceae) Growing Wild in Lebanon. Med. Aromat. Plants 2016, 5, 242-246. [CrossRef]

33. Kong, M.; Chen, X.G.; Xing, K.; Park, H.J. Antimicrobial properties of chitosan and mode of action: A state of the art review. Int. J. Food Microbiol. 2010, 144, 51-63. [CrossRef] [PubMed]

34. Champer, J.; Patel, J.; Fernando, N.; Salehi, E.; Wong, V.; Kim, J. Chitosan against cutaneous pathogens. $A M B$ Express 2013, 3, 37. [CrossRef] [PubMed]

35. Juliano, C.; Demurtas, C.; Piu, L. In vitro study of the anticandidal activity of Melaleuca alternifolia (tea tree) essential oil combined with chitosan. Flavour Fragr. J. 2008, 23, 227-231. [CrossRef]

36. Wang, L.; Liu, F.; Jiang, Y.; Chai, Z.; Li, P.; Cheng, Y.; Jing, H.; Leng, X. Synergistic antimicrobial activities of natural essential oils with chitosan films. J. Agric. Food Chem. 2011, 59, 12411-12419. [CrossRef] [PubMed] 
37. De Oliveira, K.Á.R.; Berger, L.R.R.; De Araújo, S.A.; Câmara, M.P.S.; De Souza, E.L. Synergistic mixtures of chitosan and Mentha piperita L. essential oil to inhibit Colletotrichum species and anthracnose development in mango cultivar Tommy Atkins. Food Microbiol. 2017, 66, 96-103. [CrossRef] [PubMed]

38. Mimica-Dukić, N.; Bugarin, D.; Grbović, S.; Mitić-Ćulafić, D.; Vuković-Gačić, B.; Orčić, D.; Jovin, E.; Couladis, M. Essential oil of Myrtus communis L. as a potential antioxidant and antimutagenic agent. Molecules 2010, 15, 2759-2770. [CrossRef] [PubMed]

39. Zheljazkov, V.D.; Semerdjieva, I.B.; Dincheva, I.; Kacaniova, M.; Astatkie, T.; Radoukova, T.; Schlegel, V. Antimicrobial and antioxidant activity of Juniper galbuli essential oil constituents eluted at different times. Ind. Crops Prod. 2017, 109, 529-537. [CrossRef]

40. Höferl, M.; Stoilova, I.; Schmidt, E.; Wanner, J.; Jirovetz, L.; Trifonova, D.; Krastev, L.; Krastanov, A. Chemical composition and antioxidant properties of Juniper berry (Juniperus communis L.) essential oil. Action of the essential oil on the antioxidant protection of Saccharomyces cerevisiae model organism. Antioxidants 2014, 3, 81-98. [CrossRef] [PubMed]

41. Briganti, S.; Picardo, M. Antioxidant activity, lipid peroxidation and skin disease. What's new? J. Eur. Acad. Dermatol. Venereol. 2003, 17, 663-669. [CrossRef] [PubMed]

(C) 2018 by the authors. Licensee MDPI, Basel, Switzerland. This article is an open access article distributed under the terms and conditions of the Creative Commons Attribution (CC BY) license (http:/ / creativecommons.org/licenses/by/4.0/). 